\title{
Kentlinin Ormana Bakışı: Ankara İı Merkezi Örneği
}

\author{
Üstüner BİRBEN ${ }^{1 *}$, Hasan Emre ÜNAL ${ }^{1}$ \\ ${ }^{1}$ Çankırı Karatekin Üniversitesi, Orman Fakültesi, Orman Mühendisliği Bölümü, 18200, ÇANKIRI
}

\section{Öz}

Katılımcılığın giderek önem kazandığı günümüzde ormanc1lığın şekillendirilmesi toplumun bu kaynaklara olan bakış açısı ile de yakından ilgilidir. Toplumun bu konudaki bilinç düzeyinin ne olduğunun tespiti, planlama süreçlerinin yanında orman kaynaklarının istenilen ölçüde korunması ve faydalanma şekillerine tahsisini de kolaylaştırmaktadır. $\mathrm{Bu}$ çalışma ile kentlerde yaşayan bireylerin ormana olan bakış açısı Ankara il merkezi örneğinde incelenmiștir. Anketler rastgele örnekleme yoluyla seçilen 399 kişi ile yüz yüze görüşme yöntemi kullanılarak gerçekleştirilmiştir. Anketlerden elde edilen veriler Basit Uyum Analizi yöntemi ile değerlendirilmiştir. Yapılan analizler sonucunda Ankara il merkezinde orman kaynaklarına yönelik algının cinsiyet, yaş, gelir düzeyi ve eğitim özelinde önemli değişiklikler gösterdiği saptanmıştır. Araştırma neticesinde orman kaynaklarının işlevleriyle ilgili toplumsal bilincin olup/olmadığıyla ilgili kesin bir yargıya varmanın zor olduğu görülmektedir. Bununla birlikte, orman kaynaklarının temiz ve kaliteli su üretimi (\%94), erozyonu önleme (\%84), besin kaynağı olma (\%88), temiz hava (\%88), kırsalda istihdam sağlama (\%88) gibi işlevleri konusunda kentlinin yüksek bir farkındalı̆ga sahip olduğu tespit edilmiştir. Kentlinin yoğun bir şekilde kullandığı kitle iletişim araçlarında, ormanlar ve sağladığı mal ve hizmetlere yönelik bilinç düzeyinin arttırıcı ve tanıtıcı programlara daha çok yer verilmesi önerilmektedir.

Anahtar Kelimeler: Orman kaynakları, Algı, Kentli, Ankara.

\section{Urban Peoples' Perceptions on Forest: The Case of Ankara City Center}

\begin{abstract}
In countries with the privilege of owning forest resources, policies towards these resources vary from country to country and from society to society. Today, where participatory governance is becoming more and more important, shaping forestry policies is closely related to the perspective of the society towards these resources. As well as determining the level of awareness of the society on this issue, it facilitates the planning of policy makers, and also facilitates the allocation of forest resources to the desired extent and utilization. With this study, urban peoples' perceptions towards the forest has been examined in Ankara city center. The surveys were conducted using the face-to-face survey method with 399 people selected by random sampling. The data obtained from the questionnaires were evaluated by the Simple Correspondence Analysis method. As a result of the analyzes, it has been determined that the perception of forest resources in the city center of Ankara varies significantly in terms of gender, age, income level and education. As a result of the research, it is also understood that it is difficult to make a definitive judgment about whether there is/is Urban peoples' perceptions towards the functions of forest resources. On the other hand, It has been determined that the urban people has a high awareness regarding the functions of forest resources such as clean and quality water production (94\%), preventing erosion (84\%), being a food source (88\%), clean air (88\%), rural employment (88\%). It is suggested that the mass media, which are used extensively by the inhabitants, might include more programs to increase the awareness of the forests and the goods and services it provides.
\end{abstract}

Keywords: Forest resources, Perception, Urban, Ankara. 


\section{Giriş}

Kentler ve kentlerin çevresindeki ormanlık alanların sosyal, estetik ve mimari, iklimsel ve fiziksel, ekolojik ve ekonomik birçok faydası bulunmaktadır. Bu faydalara olan talep de her geçen gün artmaktadır (Mutlu ve Cengiz, 2017). İnsanlar, orman alanlarında bugün olduğu gibi düzenli faaliyetlere geçmeden önce de ormanlarla doğrudan ilgilenmişlerdir. Ormanlar, insan toplumları için beslenme ve barınma kaynağı olmanın yanı sıra, insan toplumlarının inançlarında dahi yer almışlardır (Sevgi, 2013). Ağaç ve ormana saygı gösterme ve kutsal addetme Türk kültüründe İslamiyet öncesi dönemlerden devinimini alan bir olgudur. Öyle ki bu durum özel şartları içinde yaşamakta ve mistik, folklorik ve kültürel bir unsur olarak fonksiyonlarını sürdürmektedir (Özarslan, 2003).

Orman kaynaklarının korunmasında birçok faktör kendi iç dinamikleri ekseninde önemli etkilere sahiptir. Gelir düzeyi, eğitim, kaynağa olan ihtiyaç, toplumsal algı ilk akla gelen faktörlerdendir (Şen ve Toksoy, 2006). Bir toplumun orman algısı, olumlu açıdan kaynağın sürekliliği, olumsuz açıdan ise kaynağın tamamen tüketilmesi gibi iki önemli sonucun ortaya çıkmasına neden olabilecek güçtedir (Birben vd., 2018). Dolayısıyla, orman kaynaklarının yönetimi ve özellikle de korunması faaliyetlerinde etkinliğin artırılması (Sağlam ve Öztürk, 2008) her şeyden önce toplumun bu kaynaklara olan algısına bağlıdır. Orman kaynaklarına ilişkin alınacak kararlarda ve yapılacak uygulamalarda biyolojik, ekolojik gerekse sosyal, kültürel ve ekonomik açıdan yerel koşulları dikkate alan uygulamalar yapmak en doğru sonuçların alınmasını sağlayacaktır. Yörenin coğrafi konumu, iklimi, bitki örtüsü, biyolojik çeşitliliği, turizm potansiyeli, nüfusu, kültürü, sosyo-ekonomik gelişmişlik düzeyi, endüstriyel yapısı, doğal kaynakları gibi özellikleri yerel ölçekte ormancılığı etkileyebilecek belli başlı konular arasındadır (Yurdakul Erol, 2011). Dolayısıyla ormanların sürdürülebilir yönetimi açısından katılımcı yönetim anlayışı önemli katkılar sağlayacaktır (Yurdakul Erol ve Şahin, 2017). Öyle ki kırsal ve kentsel nüfus ormancılık politikalarının geliştirilmesi ve uygulanmasında önemli paydaşlardandır. Bu kesimlerin talepleri çatışma yönetimi ve yerel karar alma süreçleri için önemli göstergelerdendir (Yurdakul Erol, 2012a). Türkiye’de köyden kente göç olgusu demografik yapıda önemli değişikliklere neden olmuştur. Kentlerdeki hızlı nüfus artışı, kentte yaşayanların ormanlar hakkındaki geleneksel düşüncelerini değiştirmiş, toplumun ormandan beklentilerini çeşitlendirmiştir (Atmış 2004). Toplumun ormanlara olan ilgisinin düzeyi ile ormanlardan ve ormancılık etkinliklerinden ne tür beklentiler içinde olduklarını bilmeden orman toplum ilişkilerini sağlıklı temellere oturtmak güç olacaktır (Atmış 2001). Türkiye'de nüfus artış1, büyük kent ve tatil yörelerine göç, bu tip yerlerde yoğun bir yapılaşma ve şehirleşme sonucunda orman alanı-yerleşim yeri sınırları iç içe konuma gelmiştir (Ertuğrul, 2010). Özellikle kentlerde yaşayan toplum tarafından ormanların sosyo-kültürel hizmetleri daha iyi anlaşıldıkça, beklentiler de farklılaşarak artmaya devam etmektedir. Bu beklentiler olumlu ve olumsuz sonuçlar doğurabilmektedir. Örneğin rekreasyona yönelik taleplerin yeterince karşılanamaması, bu amaç için ayrılmamış orman alanları üzerinde olumsuz baskıyı artıracaktır. Dolayısıyla, ormana yönelik duyarlılıkların artırılmadığı durumlarda gelişmeler ormanlar aleyhine olacaktır (Atmış, 2003). Ormanların sürekliliğine ve korunmasına yönelik çabaların yeterli düzeyde olmadığı da genel kabul gören bir görüştür. Kentleşme Türkiye ormancılığındaki değişim ve dönüşümü etkileyen önemli faktörlerden biridir. Türkiye ormancılığını sağlıklı temellere oturtabilmek için kentleşme-ormancılık ilişkisini ayrıntılı şekilde inceleyecek çalışmalara gereksinim vardır (Atmış ve Günşen, 2016).

Ankara ili kent merkezinde gerçekleştirilen bu çalışma ile kentlinin orman algısı ortaya konulmaya çalışılmıştır. Çalışmada, orman kaynaklarına yönelik algının cinsiyet, yaş, gelir düzeyi ve eğitim değişkenleri açısından önemli farklılıklar gösterip göstermediği incelenmiştir. Bu tür çalışmalarla kentlerde yaşamlarını sürdüren insanların ormana bakış açısı yanında ormancılık faaliyetleri, ormancılık teşkilatının varlığı ve çalışmaları ile ilgili ne derece bilgi sahibi olup/olmadıkları belirlenebilmektedir. Böylece kentlerde yaşayanların ormancılık teşkilatı ve beraberinde ormanlara yönelik toplumsal farkındalı̆̆ı da arttırılabilecektir.

\section{Materyal ve Metot}

\subsection{Materyal}

Ankara ili nüfus yoğunluğu açısından önemli bir kent olması yanı sıra demografik özellikler bakımından çeşitlilik gösteren bir kenttir. Ankara ili aynı zamanda taşlaşmış orman ağacı örnekleriyle Miyosen dönemine kadar giden bir geçmişe sahiptir (Akın, 2006). Tarihi bulgular da yöredeki orman-toplum ilişkilerinin çok eski dönemlerden itibaren süregeldiğini göstermektedir. İl, Beynam Ormanı gibi koruma statüsüne sahip ormanlara da ev sahipliği yapmaktadır. Rekreasyon faaliyetleri ve özellikle de mesire alanı olarak önemli bir hizmet görmektedir. Çalışma, Ankara ili kent merkezinde Haziran-Eylül 2017 tarihleri arasında gerçekleştirilmiştir. Çalışmanın verilerini Ankara ili kent merkezinde görüşülen insanların orman algısını, ormanın işlevleri hakkında farkındalık ve 
ormancılık teşkilatı hakkında algı ve beklentilerini tespit etmeye yönelik hazırlanan anket soruları oluşturmaktadır. Araştırmada \%95 güven düzeyi ve $\% 5$ hata kabul oranı ile aşağıdaki formülden yararlanmak suretiyle araştırmanın örnek büyüklüğü hesaplanmıştır (Orhunbilge, 2000; Daşdemir 2016):

$\mathrm{n}=\left(\mathrm{N} \times \mathrm{Z}^{2} \times \mathrm{P} \times \mathrm{Q}\right) /\left(\left(\mathrm{N} \times \mathrm{d}^{2}\right)+\left(\mathrm{Z}^{2} \times \mathrm{P} \times \mathrm{Q}\right)\right)$

Formülde; n örnek büyüklüğünü, $\mathrm{N}$ ana kütleyi, $\mathrm{t}$ belirlenen güven düzeyine göre normal dağılım tablosundan alınan z değerini (\%95 güven düzeyi için 1.96), d hata kabul oranını (\%5), P ana kütle içerisinde ölçülmek istenen özelliğin bulunma oranını, Q ise bulunmama oranını ifade etmektedir. P ve Q araştırma öncesi konuyla ilgili herhangi bir fikir ileri sürülemediği durumlarda \%50-\%50 olarak alınarak, en yüksek düzeyde bir örnek büyüklüğü elde edilmektedir (Yavuz, 2000). Yapılan hesaplama neticesinde örneklem hacmi 399 kişi olarak belirlenmiştir. Anketler rastgele örnekleme yöntemi ile yapılmıştır. Örneklemin toplumu temsil düzeyini artırmak için kentin farklı yerlerinde anket yapılmasına özen gösterilmiştir. Katılımcılara demografik sorular yanında orman algısı, ormandan faydalanma şekilleri, ormancılık teşkilatı ve çalışmaları konusundaki farkındalık ile teşkilattan beklentiler, ormanların işlevlerine yönelik farkındalığı ölçmeye yönelik sorular sorulmuştur.

\subsection{Metot}

Çalışmada katılımcılardan elde edilen verilere iki farklı test uygulanmıştır. Bunlardan biri parametreler arasındaki ilişki durumunu test etmeye yarayan Ki-kare bağımsızlık testi diğeri de kategorilerin değişkenleri arasındaki uyumu grafiksel bir yolla inceleyen basit uyum analizidir. Katılımcılara ait anket formları SPSS paket programında bilgisayar ortamına aktarılarak istatistiksel çözümlemeler için veri tabanı oluşturulmuştur.

Cinsiyet, eğitim ve yaş değişkenleri ile anket formunda katılımcılara sorulan ormandan faydalanma şekilleri, orman bakış açısı, biyoçeşitliliğin korunmasında orman etkisi, kaliteli ve temiz hava sağlamada orman etkisi, erozyonla toprak aşınmasının engellenmesinde orman etkisi, ormanların kırsalda iş imkanı sağlaması, odun dışı orman ürünü işlevi, kültürel değerlerin korunmasında ormanların etkisi, küresel ısınmanın azaltılmasında orman etkisi, ormanların kent yaşamını desteklemesi gibi sorulara ait parametreler arasındaki ilişkinin durumunu tespit etmek amacıyla SPSS 23 paket programında Ki-Kare Bağımsızlık Testi uygulaması yapılmıştır (Bkz Tablo 5).

Ki-Kare bağımsızlık testi; X ve Y değişkenlerinin alt sınıfları arasında bir bağımlılık olup olmadığını belirlemek amacıyla yapılmaktadır. Buna göre; $2 * 2$ ya da $\mathrm{r}^{*} \mathrm{c}$ tipindeki çapraz tablolarda gözlenen frekansların, marjinal olasılıklar yaklaşımına göre hesaplanan teorik frekanslara benzerliğini tespit eder. Bu testin hipotezleri (Özdamar, 2002; Akalp, 2016):

$\mathrm{H}_{0}$ : İlişkisi sorgulanan iki değişken ya da özellik arasında bir ilişki yoktur (Bağımsızlık vardır)

$\mathrm{H}_{1}$ : İlişkisi sorgulanan iki değişken ya da özellik arasında bir ilişki vardır (Bağımsızlık yoktur)

Çalışmada arasında ilişki aranan değişkenlere ait hipotezler şu şekildedir (bkz. Tablo 5):

* $\mathrm{H}_{0}$ : Cinsiyet, yaş, eğitim ile ormandan faydalanma şekli arasında ilişki yoktur

$\mathrm{H}_{1}$ :Cinsiyet, yaş, eğitim ile ormandan faydalanma şekli arasında ilişki vardır

* $\mathrm{H}_{0}$ : Cinsiyet, yaş, eğitim ile ormana bakış açısı arasında ilişki yoktur

$\mathrm{H}_{1}$ : Cinsiyet, yaş, eğitim ile ormana bakış açısı arasında ilişki vardır

* $\mathrm{H}_{0}$ : Cinsiyet, yaş, eğitim ile biyoçeşitliliğin korunmasında ormanların etkisi arasında anlamlı ilişki yoktur

$\mathrm{H}_{1}$ : Cinsiyet, yaş, eğitim ile biyoçeşitliliğin korunmasında ormanların etkisi arasında anlamlı ilişki vardır

* $\mathrm{H}_{0}$ : Cinsiyet, yaş ile kaliteli ve temiz hava sağlamada orman etkisi arasında anlamlı ilişki yoktur

$\mathrm{H}_{1}$ : Cinsiyet, yaş ile kaliteli ve temiz hava sağlamada orman etkisi arasında anlamlı ilişki vardır

* $\mathrm{H}_{0}$ : Cinsiyet, yaş, eğitim ile erozyonla toprak aşınmanın engellenmesine orman etkisi arasında ilişki yoktur

$\mathrm{H}_{1}$ : Cinsiyet, yaş, eğitim ile erozyonla toprak aşınmanın engellenmesine orman etkisi arasında ilişki vardır

* $\mathrm{H}_{0}$ : Cinsiyet, yaş, eğitim ile ormanların kırsalda iş imkânı sağlaması arasında ilişki yoktur

$\mathrm{H}_{1}$ : Cinsiyet, yaş, eğitim ile ormanların kırsalda iş imkânı sağlaması arasında ilişsi vardır

* $\mathrm{H}_{0}$ : Cinsiyet, eğitim ile ormanların odun dışı orman ürünü sağlaması arasında ilişki yoktur

$\mathrm{H}_{1}$ : Cinsiyet, eğitim ile ormanların odun dışı orman ürünü sağlaması arasında ilişki vardır 
* $\mathrm{H}_{0}$ : Cinsiyet, eğitim ile ormanların kültürel değerlerin korunmasındaki etkisi arasında ilişki yoktur $\mathrm{H}_{1}$ : Cinsiyet, eğitim ile ormanların kültürel değerlerin korunmasındaki etkisi arasında ilişki vardır

* $\mathrm{H}_{0}$ : Yaş, eğitim ile küresel ısınmanın azaltılmasında ormanların etkisi arasında ilişki yoktur $\mathrm{H}_{1}$ : Yaş, eğitim ile küresel ısınmanın azaltılmasında ormanların etkisi arasında ilişki vardır

* $\mathrm{H}_{0}$ : Eğitim ile ormanların kent yaşamını desteklemesi arasında ilişki yoktur $\mathrm{H}_{1}$ : Eğitim ile ormanların kent yaşamını desteklemesi arasında ilişki vardır

Çalışmada ayrıca Ki-Kare Bağımsızlık Testi dışında elde edilen veri tabanları ile değişkenlerin kategorileri arasındaki ilişkilerin (uyumun) grafiksel olarak incelendiği başka bir istatiksel teknik olan Basit Uyum Analizi kullanılmıştır.

Uyum Analizi (Correspondence Analysis), çapraz tablo haline getirilmiş kategorik verilerin sıra ve sütunlarının birlikte değişimlerini, daha az boyutlu bir uzayda grafiksel olarak göstermeyi amaçlayan çok değişkenli istatiksel bir tekniktir (Özdamar, 2010; Kılıç, 2016). Çapraz tabloda yer alan değişken sayısının 2 olduğu durumlarda Basit Uyum Analizi, 3 ve daha fazla değişkenin olduğu durumlarda ise Çoklu Uyum Analizi olarak adlandırılmaktadır. Uyum analizi kısıtlamaların az olduğu ve çapraz tablodaki sıklıkların pozitif olması dışında herhangi bir varsayımı ve anlamlılık testinin de olmadığı bir analizdir (Kılıç, 2016). Çalışmada SPSS 23 paket programı yardımıyla eğitim durumu kategorileri ile ormandan faydalanma şekli, ormana bakış açısı, teşkilat çalışmaları hakkında bilgi sahibi olup/olmama; gelir durumu ile ormandan faydalanma şekli, ormana bakış açısı ile ormana bakış açısı ve teşkilattan beklenti, ormandan faydalanma şekli ve ormana bakış açısına dair alınan cevapların kategorileri arasındaki uyum belirlenmiştir.

\section{Bulgular ve Tartışma}

Anket çalışmasına katılan 399 katılımcının demografik özelliklerine ait bilgiler, Tablo 1'de verilmiştir. Cinsiyete göre frekans ve yüzde dağılımının gösterildiği Tablo 1'e göre, 399 kişinin \%21.3'ünü erkek ve \%78.7'sini kadın katılımcılar oluşturmaktadır.

Tablo 1. Katılımcıların demografik özelliklerine ait frekans ve yüzde dağılımı.

\begin{tabular}{llll}
\hline Kategori & Değişken & Frekans & Yüzde \\
& & $\mathbf{N}$ & \% \\
\hline Cinsiyet & Erkek & 85 & 21.3 \\
& Kadın & 314 & 78.7 \\
\hline Yaş & $16-25$ & 101 & 25.3 \\
& $26-40$ & 50 & 12.5 \\
& $41-60$ & 245 & 61.4 \\
& 61 ve üzeri & 3 & 8 \\
\hline Eğitim & İlkokul & 19 & 4.8 \\
& Lise & 37 & 9.3 \\
& Önlisans/Lisans & 309 & 77.4 \\
& Yüksek Lisans & 15 & 3.8 \\
& Doktora & 19 & 4.8 \\
\hline Meslek & Özel/Kamu Personel, Memur & 25 & 6.3 \\
& Özel/Kamu İşçi & 231 & 57.9 \\
& Esnaf / zanaatkâr & 23 & 5.8 \\
& Esnaf / ticaret erbabı & 15 & 3.8 \\
& Diğer & 105 & 26.3 \\
\hline
\end{tabular}

Tablo 1'de yaş kategorilerinin dağılımına bakıldığında en yüksek yüzdeye \%61'lik bir oranla 41-60 yaş grubu sahip olmuştur. Diğer önemli bir orana sahip yaş grubu da \%25,3'lük oranıyla 16-25 yaş grubudur. Katılımcıların eğitim durumlarına yönelik oransal dağılımlarda üniversite eğitimlilerin çok büyük bir çoğunluğa sahip olduğu görülmektedir. Buna göre, katılımcıların \%77,4’ü önlisans/lisans eğitimi aldığını belirtmiştir. Katılımcıların \%9,3'ü ise lise mezunudur. İlkokul mezunu, master ve doktora eğitimi alanların oranlarının ise birbirine yakın olduğu görülmektedir. Ankete katılanların meslek durumlarına göre dağılımlarında; \%57,9 ile özel/kamu işçi 
olanlar ilk sıradadır. Bu grubu \%6,3 özel/kamu personel, memur, \%5,8 ile de esnaf/zanaatkar takip etmiştir. Ankete katılanların \%26,3'ü sıralanan meslek gruplarının dışında bir mesleğe sahip olduğunu belirtmiştir.

Ki-Kare bağımsızlık testi ile elde edilen ve aralarında \%95 güven düzeyinde anlamlı ilişki tespit edilen değişkenlere ilişkin sonuçlar ise Tablo 2'de verilmiştir.

Tablo 2. Aralarında anlamlı ilişki bulunan değişkenler ve değerleri.

\begin{tabular}{|c|c|c|c|}
\hline İlişki Aranan Değişken & Ki-Kare Değeri & Anlamlılık Değeri & İlişki Durumu \\
\hline $\begin{array}{l}\text { Cinsiyet-ormandan faydalanma } \\
\text { şekilleri }\end{array}$ & $\chi^{2}$ hesap $=40.766$ & $\mathrm{P}=0.000<0.05$ & Anlamlı ilişki var \\
\hline Cinsiyet-ormana bakış açısı & $\chi_{\text {hesap }}^{2}=210.785$ & $P=0.000<0.05$ & Anlamlı ilişki var \\
\hline $\begin{array}{l}\text { Cinsiyet-biyoçeşitliliğin } \\
\text { korunmasında orman etkisi }\end{array}$ & $\chi_{\text {hesap }}^{2}=103.270$ & $\mathrm{P}=0.000<0.05$ & Anlamlı ilişki var \\
\hline $\begin{array}{l}\text { Cinsiyet-kaliteli ve temiz } \\
\text { sağlamada orman etkisi }\end{array}$ & $\chi_{\text {hesap }}^{2}=7.455$ & $\mathrm{P}=0.024<0.05$ & Anlamlı ilişki var \\
\hline $\begin{array}{l}\text { Cinsiyet- erozyonla toprak } \\
\text { aşınmanın engellenmesine } \\
\text { ormanın etkisi }\end{array}$ & $\chi_{\text {hesap }}^{2}=14.693$ & $\mathrm{P}=0.001<0.05$ & Anlamlı ilişki var \\
\hline $\begin{array}{l}\text { Cinsiyet-ormanların kırsalda iş } \\
\text { imkanı sağlaması }\end{array}$ & $\chi_{\text {hesap }}^{2}=13.521$ & $P=0.000<0.05$ & Anlamlı ilişki var \\
\hline $\begin{array}{l}\text { Cinsiyet- ormanın odun dişı } \\
\text { orman ürünü sağlama işlevi }\end{array}$ & $\chi_{\text {hesap }}^{2}=39.649$ & $P=0.000<0.05$ & Anlamlı ilişki var \\
\hline $\begin{array}{l}\text { Cinsiyet- ormanların kültürel } \\
\text { değerlerin korunmasında etkisi }\end{array}$ & $\chi_{\text {hesap }}^{2}=108.284$ & $\mathrm{P}=0.000<0.05$ & Anlamlı ilişki var \\
\hline $\begin{array}{l}\text { Yaş- ormandan faydalanma } \\
\text { şekilleri }\end{array}$ & $\chi_{\text {hesap }}^{2}=371.699$ & $\mathrm{P}=0.000<0.05$ & Anlamlı ilişki var \\
\hline Yaş - ormana bakış açısı & $\chi_{\text {hesap }}^{2}=438.932$ & $P=0.000<0.05$ & Anlamlı ilişki var \\
\hline $\begin{array}{l}\text { Yaş- biyoçeşitliliğin } \\
\text { korunmasında orman etkisi }\end{array}$ & $\chi_{\text {hesap }}^{2}=345.819$ & $\mathrm{P}=0.000<0.05$ & Anlamlı ilişki var \\
\hline $\begin{array}{l}\text { Yaş- küresel ısınmanın } \\
\text { azaltılmasında ormanlar }\end{array}$ & $\chi_{\text {hesap }}^{2}=52.164$ & $\mathrm{P}=0.000<0.05$ & Anlamlı ilişki var \\
\hline $\begin{array}{l}\text { Yaş- kaliteli ve temiz } \\
\text { sağlamada orman etkisi }\end{array}$ & $\chi_{\text {hesap }}^{2}=57.776$ & $\mathrm{P}=0.000<0.05$ & Anlamlı ilişki var \\
\hline $\begin{array}{l}\text { Yaş- erozyonla toprak } \\
\text { aşınmanın engellenmesine } \\
\text { ormanın etkisi }\end{array}$ & $\chi_{\text {hesap }}^{2}=110.990$ & $P=0.000<0.05$ & Anlamlı ilişki var \\
\hline $\begin{array}{l}\text { Yaş- ormanların kırsalda iş } \\
\text { imkânı sağlaması }\end{array}$ & $\chi^{2}$ hesap $=70.674$ & $\mathrm{P}=0.000<0.05$ & Anlamlı ilişki var \\
\hline $\begin{array}{l}\text { Eğitim- ormandan faydalanma } \\
\text { şekli }\end{array}$ & $\chi^{2}$ hesap $=83.012$ & $P=0.000<0.05$ & Anlamlı ilişki var \\
\hline Eğitim-ormana bakış açısı & $\chi_{\text {hesap }}^{2}=250.729$ & $P=0.000<0.05$ & Anlamlı ilişki var \\
\hline $\begin{array}{l}\text { Eğitim- biyoçeşitliliğin } \\
\text { korunmasında orman etkisi }\end{array}$ & $\chi_{\text {hesap }}^{2}=97.577$ & $P=0.000<0.05$ & Anlamlı ilişki var \\
\hline $\begin{array}{l}\text { Eğitim- küresel ısınmanın } \\
\text { azaltılmasında ormanlar }\end{array}$ & $\chi_{\text {hesap }}^{2}=45.660$ & $\mathrm{P}=0.000<0.05$ & Anlamlı ilişki var \\
\hline $\begin{array}{l}\text { Eğitim- erozyonla toprak } \\
\text { taşınmanın engellenmesine } \\
\text { ormanın etkisi }\end{array}$ & $\chi^{2}$ hesap $=45.660$ & $\mathrm{P}=0.000<0.05$ & Anlamlı ilişki var \\
\hline $\begin{array}{l}\text { Eğitim-ormanların kırsalda iş } \\
\text { imkânı sağlaması }\end{array}$ & $\chi^{2}$ hesap $=110.969$ & $\mathrm{P}=0.000<0.05$ & Anlamlı ilişki var \\
\hline $\begin{array}{l}\text { Eğitim-odun dişı orman ürünü } \\
\text { sağlama işlevi }\end{array}$ & $\chi_{\text {hesap }}^{2}=200.149$ & $\mathrm{P}=0.000<0.05$ & Anlamlı ilişki var \\
\hline $\begin{array}{l}\text { Eğitim- ormanların kültürel } \\
\text { değerleri koruması }\end{array}$ & $\chi_{\text {hesap }}^{2}=130.317$ & $\mathrm{P}=0.000<0.05$ & Anlamlı ilişki var \\
\hline $\begin{array}{l}\text { Eğitim-ormanların kent } \\
\text { yaşamını desteklemesi }\end{array}$ & $\chi_{\text {hesap }}^{2}=31.514$ & $P=0.000<0.05$ & Anlamlı ilişki var \\
\hline
\end{tabular}


Tablo 2'ye göre; Cinsiyet, yaş, eğitim değişkenleri ile ormandan faydalanma şekli, ormana bakış açısı, biyoçeşitliliğin korunmasında ormanların etkisi, erozyonla toprak aşınmanın engellenmesine orman etkisi, ormanların kırsalda iş imkânı sağlaması ve cinsiyet, yaş değişkenleri ile kaliteli ve temiz hava sağlamada orman etkisi arasında anlamlı bir ilişki söz konusudur. Ayrıca, cinsiyet, eğitim ile ormanların odun dışı orman ürünü sağlaması, ormanların kültürel değerlerin korunmasındaki etkisi; yaş, eğitim ile küresel ısınmanın azaltılmasında ormanların etkisi ve eğitim ile ormanların kent yaşamını desteklemesi arasında da anlamlı bir ilişki söz konusudur. Buna karşı1ık; Cinsiyet ile küresel ısınmanın azaltılmasında ormanların etkisinin olup olmadığ $1\left(\mathrm{X}^{2}\right.$ hesap $=2.911$, $\mathrm{P}=0.233>0.05$ ), sorularına verilen cevaplar arasında $\% 95$ güven düzeyinde istatiksel olarak anlamlı bir ilişki bulunmamaktadır. Eğitim durumu değişkeninin kategorileri ile ormanlardan faydalanma şekli, ormana bakış açısı, teşkilat çalışmaları; gelir durumu değişkeninin kategorileri ile ormanlardan faydalanma şekli, ormana bakış açısı; ormana bakış açısı değişkeninin kategorileriyle teşkilattan beklenti ve ormanlardan faydalanma şekilleri sorularının kategorileri arasındaki uyumun gösterildiği Basit Uyum Analizi sonuçları aşağıda Tablo 3'ten başlayarak verilmiştir.

Tablo 3. Eğitim durumuna göre ormandan faydalanma şekilleri.

\begin{tabular}{lllll}
\hline Eğitim Durumu & Yakacak odun & Avlanma & Piknik, kamp, spor & Toplam \\
\hline İlkokul & 1 & 10 & 8 & 93 \\
Lise & 7 & 1 & 29 & 141 \\
Üniversite & 4 & 36 & 261 & 119 \\
Lisansüstü & 3 & 3 & 36 & 3 \\
Toplam & $\mathbf{1 5}$ & $\mathbf{5 0}$ & $\mathbf{3 3 4}$ & $\mathbf{3 9 9}$ \\
\hline
\end{tabular}

Tablo 3'e göre eğitim durumuna göre ormandan ağırlıklı olarak faydalanma şekli piknik, kamp, sportif etkinlikler şeklindedir. Avlanma şeklinde ormandan faydalanmanın da özellikle ilkokul ve üniversite eğitimliler arasında yaygın olduğu söylenebilir.

Eğitim durumu kategorilerine göre ormandan faydalanma şekilleri sorusunun cevap kategorileri uyumunun belirlenmesi amaciyla yapılan basit uyum analizi neticesinde elde edilen boyutlara ve eylemsizlik (inertia) değerlerine ilişkin veriler Tablo 4'te sunulmuştur.

Tablo 4. Basit uyum analizi özeti.

\begin{tabular}{lllllll}
\hline Boyut & $\begin{array}{l}\text { Tekil } \\
\text { Değer }\end{array}$ & $\begin{array}{l}\text { Eylemsizlik } \\
\text { değeri }\end{array}$ & Ki-Kare & Anlamlılık & \multicolumn{2}{l}{ Eylemsizlik Oranı } \\
\cline { 5 - 6 } & & & & Hesaplanan & Kümülatif \\
\hline 1 & 0,301 & 0,09 & 61,424 & $0,000 \mathrm{a}$ & 0,587 & 0,587 \\
2 & 0,252 & 0,064 & & & 0,413 & 1,000 \\
Toplam & & 0,154 & & & 1,000 & 1,000 \\
\hline
\end{tabular}

Tablo 4 incelendiğinde eylemsizliğin 0'dan farklı olup olmadığına yönelik yapılan Ki-Kare analizi neticesinde toplam eylemsizliğin 0'dan farklı olduğu görülmektedir $\left(\chi^{2}=61,424 \mathrm{p}<0,05\right)$. Buna göre satır ve sütun değişkenlerinin birbirinden bağımsız olmadığ 1 yani aralarında bir ilişki olduğunu söylemek mümkündür. Tabloda boyutların etki derecelerinin belirlendiği eylemsizlik oranı sütununda görüleceği üzere birinci boyut toplam eylemsizliğin \%58,7'sini ve ikinci boyut ise \%41,3'ünü açıklamaktadır. Bu değerlere göre, 1. boyut, 2. boyuta göre çapraz tablonun kategorileri arasındaki ilişkileri daha fazla açıklamaktadır. Şekil 1'de kategorilerin düzlemde gösterimi verilmiştir. 


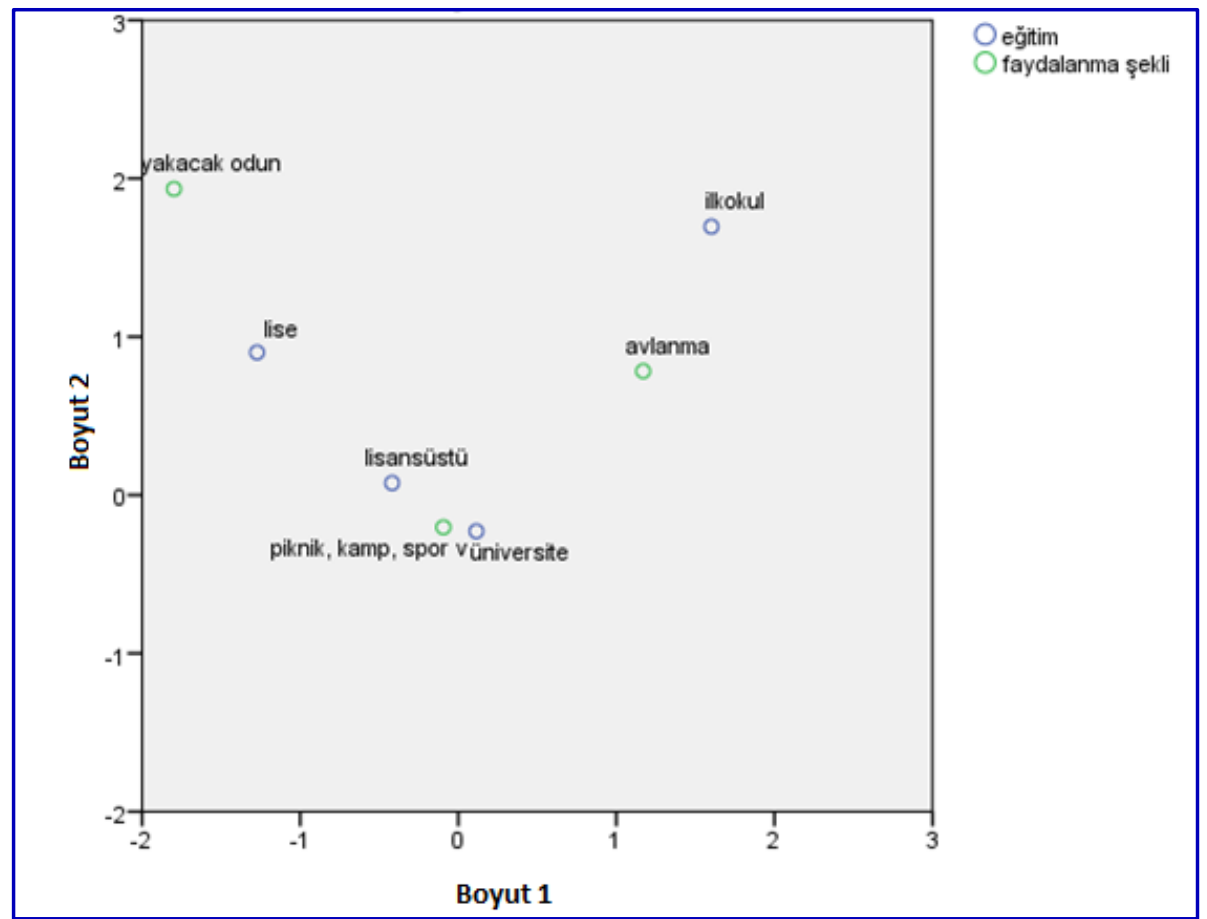

Şekil 1. Satır ve sütun noktalarının düzlemde birlikte gösterimi.

Tablo 4'te yer alan uyum analizi özetine göre, satır-sütun değişken kategorilerinin birlikte gösterildiği uyum analizi grafiği 1. ve 2. boyuta göre yorumlanacaktır. Şekil 1'e göre eğitim durumlarının konumlarına bakıldığında ormandan faydalanma şekli ile eğitim durumları arasındaki ilişkilerle ilgili olarak; üniversite ve lisansüstü eğitimi olanların ormanlardan faydalanma şekli piknik, kamp, spor vb şeklindedir. Avlanmanın ilkokul ve üniversite eğitimi olanlar arasında daha yaygın olduğu buna karşılık eğitim düzeyi lise olanların ise ormandan faydalanma şeklinin yakacak odun şeklinde olduğu söylenebilir.

Tablo 5. Eğitim durumuna göre ormanlara bakış açısı.

\begin{tabular}{llllll}
\hline Eğitim Durumu & Yeşillik & Yaşam & Rekreasyon & Erozyonla mücadele & Toplam \\
\hline İlkokul & 2 & 12 & 4 & 1 & 19 \\
Lise & 19 & 13 & 3 & 2 & 37 \\
Üniversite & 43 & 12 & 40 & 206 & 301 \\
Lisansüstü & 31 & 3 & 3 & 5 & 42 \\
Toplam & $\mathbf{9 5}$ & $\mathbf{4 0}$ & $\mathbf{5 0}$ & $\mathbf{2 1 4}$ & $\mathbf{3 9 9}$ \\
\hline
\end{tabular}

Eğitim düzeyleri açısından ormana bakış açılarına bakıldığında ilkokul mezunları ormanı yaşam kaynağı, lise mezunları yine yaşam kaynağı ve yeşil alan, lisansüstü eğitime sahip olanların büyük çoğunluğu da yeşil alan olarak görmektedir. Ormana bakış açısı bakımından farkındalığı en fazla olan grubun üniversiteliler ve üniversite mezunu olanlar olarak dikkat çekmektedir.

Tablo 6. Basit uyum analizi özeti.

\begin{tabular}{lllllll}
\hline Boyut & $\begin{array}{l}\text { Tekil } \\
\text { Değer }\end{array}$ & $\begin{array}{l}\text { Eylemsizlik } \\
\text { değeri }\end{array}$ & Ki-Kare & Anlamlılık & \multicolumn{2}{l}{ Eylemsizlik Oranı } \\
\cline { 6 - 7 } & 0,603 & 0,363 & 209,894 & $0,000 \mathrm{a}$ & 0,690 & Kümülatif \\
\hline 1 & 0,402 & 0,162 & & & 0,308 & 0,690 \\
2 & 0,034 & 0,001 & & 0,002 & 0,998 \\
3 & & 0,526 & & 1,000 & 1,000 \\
Toplam & & & & & 1,000 \\
\hline
\end{tabular}

Tablo 6 incelendiğinde eylemsizliğin 0'dan farklı olup olmadığına yönelik yapılan Ki-Kare analizi neticesinde toplam eylemsizliğin 0'dan farklı olduğu görülmektedir $\left(\chi^{2}=209,1894 ; p<0,05\right)$. Buna göre satır ve sütun 
değişkenlerinin birbirinden bağımsız olmadığı yani aralarında bir ilişki olduğunu söylemek mümkündür. Tabloya göre, boyutların etki derecelerinin belirlendiği eylemsizlik oranı sütununda görüleceği üzere birinci boyut toplam eylemsizliğin \%69'unu açıklamaktadır. Şekil 2'de kategorilerin düzlemde gösterimi verilmiştir.

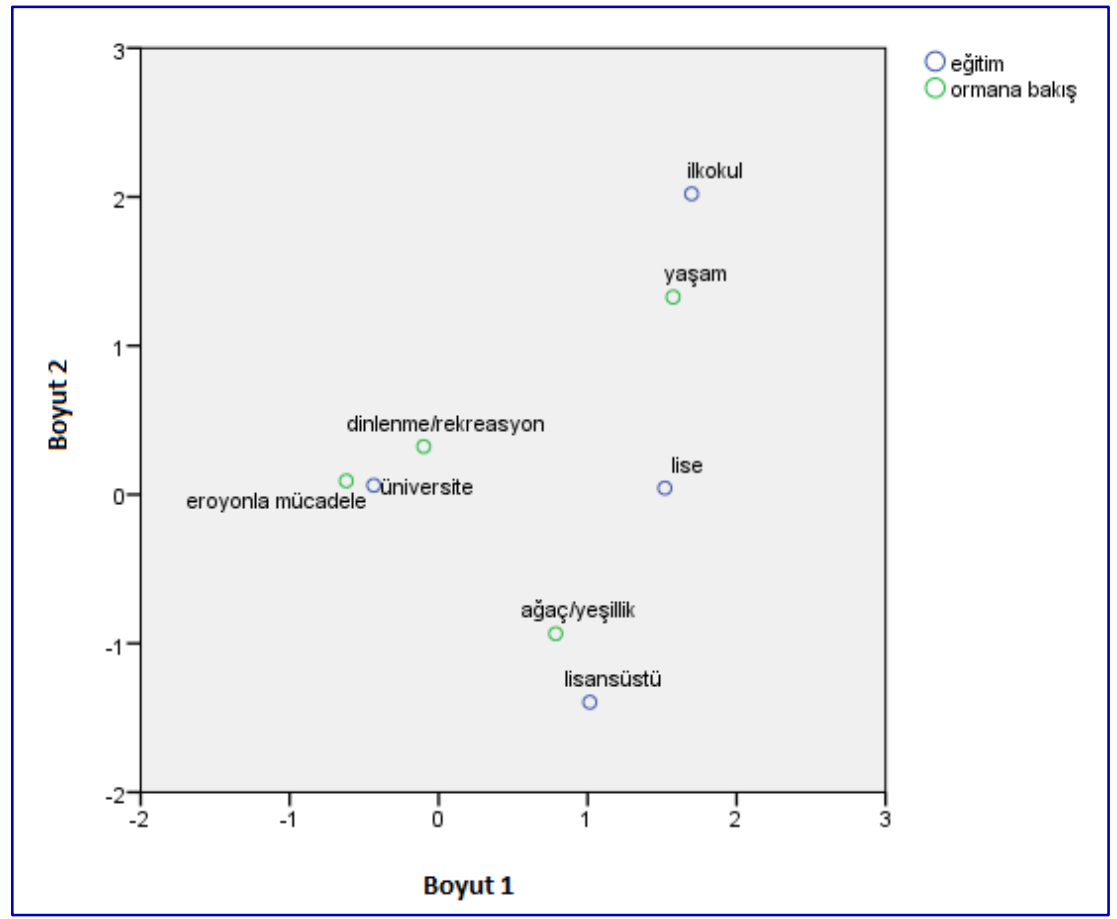

Şekil 2. Satır ve sütun noktalarının düzlemde birlikte gösterimi.

Şekil 2'ye göre eğitim durumu üniversite olanlar ormanı hem dinlenme/rekreasyon alanı hem de erozyonla mücadele imkânı olarak görmektedir. Bunun yanında üniversite, lise ve lisansüstü eğitimlilerin ormanları ağaç/yeşil alan olarak da gördükleri söylenebilir. Lise eğitimi olanlar için ormanlar yaşam alanı ve dinlenme/rekreasyon imkânı olarak görülürken, ilkokul mezunları için ormanlar bir yaşam alanını ifade etmektedir.

Tablo 7. Eğitim durumuna göre teşkilat çalışmaları hakkında bilgi.

\begin{tabular}{lllll}
\hline Eğitim Durumu & Biliyorum & Olabilir & Bilmiyorum & Toplam \\
\hline İlkokul & 1 & 1 & 17 & 19 \\
Lise & 16 & 8 & 13 & 37 \\
Üniversite & 44 & 49 & 208 & 301 \\
Lisansüstü & 8 & 19 & 15 & 42 \\
Toplam & $\mathbf{6 9}$ & $\mathbf{7 7}$ & $\mathbf{2 5 3}$ & $\mathbf{3 9 9}$ \\
\hline
\end{tabular}

Tablo 7'ye göre teşkilat çalışmaları hakkında bilgi sahibi olunması konusunda hâkim olan görüş yapılan çalışmaların bilinmediği yönündedir. Lise eğitimlilerin yaklaşık yarısı, ilkokul mezunlarının neredeyse tamamı ve üniversite ve lisansüstü eğitimi olanlarında çok büyük bir kısmı teşkilat tarafından yapılan çalışmalar konusunda bilgi sahibi değildir.

Tablo 8. Basit uyum analizi özeti.

\begin{tabular}{lllllll}
\hline Boyut & $\begin{array}{l}\text { Tekil } \\
\text { Değer }\end{array}$ & $\begin{array}{l}\text { Eylemsizlik } \\
\text { değeri }\end{array}$ & Ki-Kare & Anlamlılık & Eylemsizlik Oranı & \\
\cline { 6 - 7 } & & & & Hesaplanan & Kümülatif \\
\hline 1 & 0,302 & 0,091 & 48,747 & $0,000 \mathrm{a}$ & 0,747 & 0,747 \\
2 & 0,176 & 0,031 & & & 0,253 & 1,000 \\
Toplam & & 0,122 & & & 1,000 & 1,000 \\
\hline
\end{tabular}


Tablo 8'e göre, satır ve sütun değişkenlerinin birbirinden bağımsız olmadığı yani aralarında bir ilişki olduğunu söylenebilir $\left(\chi^{2}=48,747 ; \mathrm{p}<0,05\right)$. Tabloda boyutların etki derecelerinin belirlendiği eylemsizlik oranı sütununda görüleceği üzere birinci boyut toplam eylemsizliğin \%74'ünü açıklamaktadır. Dolayısıyla Şekil 3 için açıklamalar birinci boyuta göre yapılacaktır.

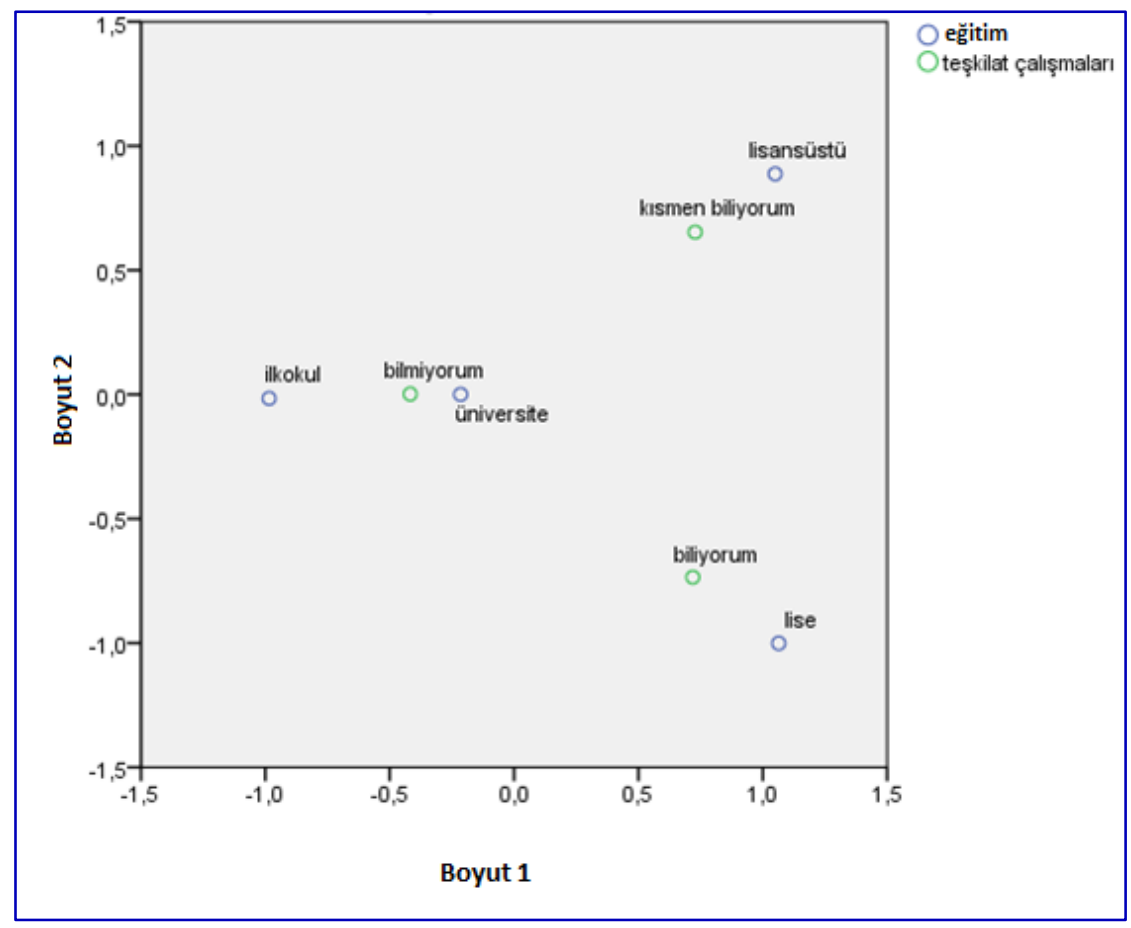

Şekil 3. Satır ve sütun noktalarının düzlemde birlikte gösterimi.

Satır ve sütun noktalarının düzlemde birlikte gösterildiği Şekil 3'den de görüleceği üzere, ilkokul mezunu ve üniversite eğitimi olanlar teşkilat çalışmaları hakkında yeterli bilgi sahibi değildir. Lise mezunlarının teşkilat çalışmaları hakkında bilgi sahibi olduğu buna karşılık lisansüstü eğitimi olanların ise bu konuda kısmen bilgisi olduğu söylenebilir. Üniversite eğimi olanların teşkilat çalışmalarıyla ilgili olarak birbirine benzer şekilde kısmen bilgi sahibi ve bilgisi olduğunu da söylemek mümkündür.

Tablo 9. Gelir durumuna göre ormandan faydalanma şekilleri.

\begin{tabular}{llllll}
\hline Gelir Durumu & Yakacak odun & Avlanma & Piknik, kamp, spor & Diğer & Toplam \\
\hline 2001-3000 TL & 1 & 29 & 12 & 1 & 43 \\
3001-4000 TL & 5 & 10 & 225 & 15 & 255 \\
4001 + TL & 6 & 3 & 29 & 63 & 101 \\
Toplam & $\mathbf{1 2}$ & $\mathbf{4 2}$ & $\mathbf{2 6 6}$ & $\mathbf{7 9}$ & $\mathbf{3 9 9}$ \\
\hline
\end{tabular}

Gelir durumuna göre ormandan faydalanma şekillerinin frekans dağılımlarının verildiği Tablo 12'ye göre, gelir düzeyi 2.001-3.000 TL olanlar içinden büyük çoğunluğu avlanma ve piknik, kamp, spor imkanlarından; geliri 3.001-4.000 TL olanların çok önemli bir kısmı piknik, kamp, spor imkanı olarak ve 4.001+ TL gelir beyan eden katılımcılarda ise piknik ,kamp, spor imkanlarıyla sunulan seçenekler dışında başka imkanlar şeklinde faydalandıkları görülmektedir.

Tablo 10. Basit uyum analizi özeti.

\begin{tabular}{lllllll}
\hline Boyut & $\begin{array}{l}\text { Tekil } \\
\text { Değer }\end{array}$ & $\begin{array}{l}\text { Eylemsizlik } \\
\text { değeri }\end{array}$ & Ki-Kare & Anlamlılık & Eylemsizlik Oranı & \\
\cline { 5 - 6 } & & & & Hesaplanan & Kümülatif \\
\hline 1 & 0,664 & 0,441 & 325,615 & $0,000 \mathrm{a}$ & 0,540 & 0,540 \\
2 & 0,612 & 0,375 & & & 0,460 & 1,000 \\
Toplam & & 0,816 & & & 1,000 & 1,000 \\
\hline
\end{tabular}


Tablo 10'da verilen uyum analizi özetinden de anlaşılacağı üzere tablodaki ilişkileri açıklamada iki boyutun da kullanılabileceği anlaşılmaktadır. Zira, 1. Boyut toplam eylemsizliğin \%54'ünü ve 2. Boyut ise \%46'sını açıklamaktadır. Tabloya göre, Ki-kare değerinin de anlamlı olduğu görülmektedir $(\chi 2=325,615 ; p<0,05)$. Buna göre, satır ve sütun değişkenleri birbirlerinden bağımsız değillerdir. Yani satır sütun değişkenleri arasında bir ilişki söz konusudur.

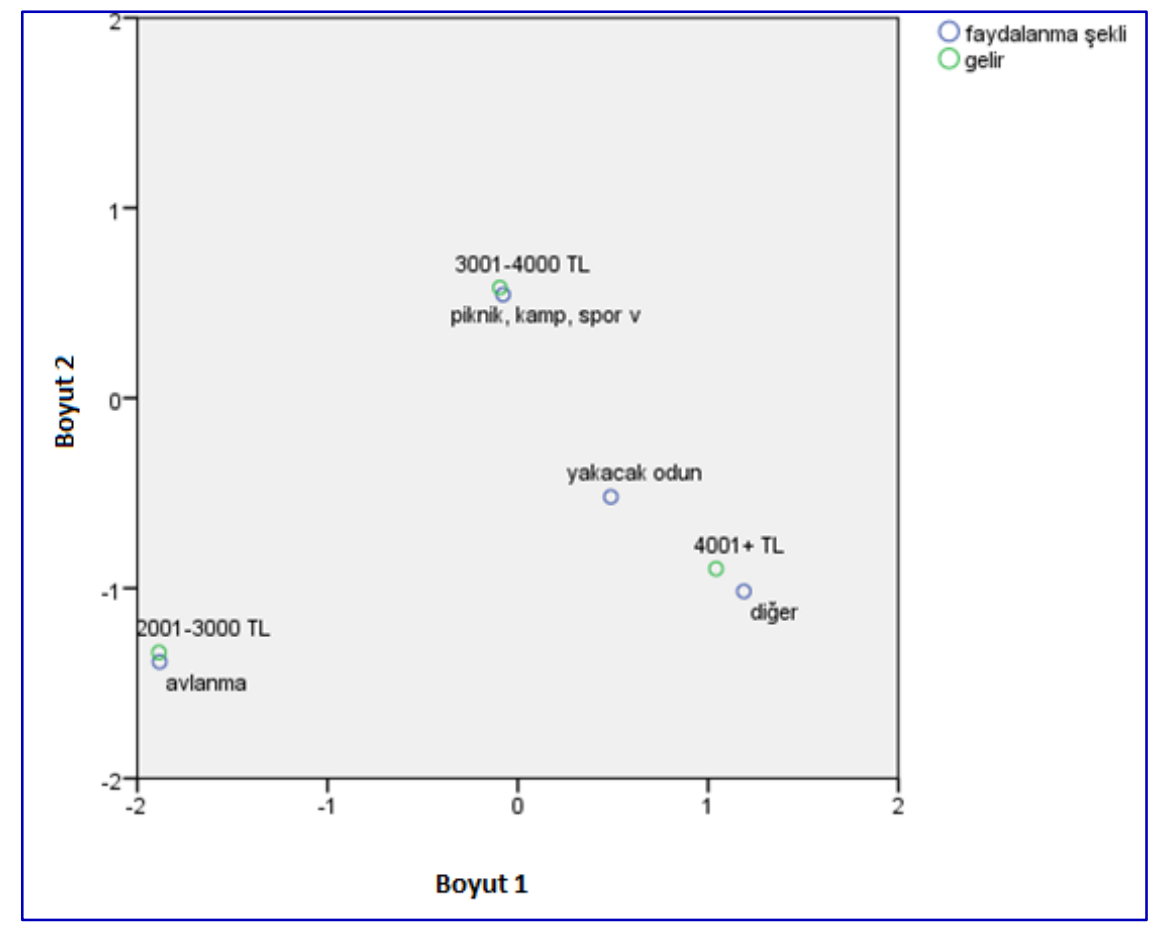

Şekil 4. Satır ve sütun noktalarının düzlemde birlikte gösterimi.

Şekil 4'e göre geliri 3.001-4.000 TL olan katılımcılar ormandan piknik, kamp, spor amaçlı faydalanırken 4.001+TL gelire sahip olanların ormandan yakacak odun ve diğer seçenekler şeklinde faydalandıkları söylenebilir. 2.001-3.000 TL gelire sahip katılımcılar ise ormanlardan avlanma amaçlı olarak faydalanmaktadır.

Tablo 11. Gelir durumuna göre ormanlara bakış açısı.

\begin{tabular}{lllllll}
\hline Gelir Durumu & Yeşillik & $\begin{array}{l}\text { Temiz } \\
\text { hava }\end{array}$ & Yaşam & Rekreasyon & $\begin{array}{l}\text { Erozyonla } \\
\text { mücadele }\end{array}$ & Toplam \\
\hline 2001-3000 TL & 25 & 1 & 12 & 4 & 1 & 43 \\
3001-4000 TL & 20 & 1 & 15 & 7 & 212 & 255 \\
4001 + TL & 50 & 8 & 3 & 39 & 1 & 101 \\
Toplam & $\mathbf{9 5}$ & $\mathbf{1 0}$ & $\mathbf{3 0}$ & $\mathbf{5 0}$ & $\mathbf{2 1 4}$ & $\mathbf{3 9 9}$ \\
\hline
\end{tabular}

Katılımcıların ormana bakış açılarının ortaya konduğu Tablo 11'e göre, geliri 2.001-3.000TL olanların orman anlayışı yeşillik ve yaşam alanıyken, 3.001-4.000TL gelire sahip olanların çok büyük bir kısmı için ormanlar erozyon önleyici bir kaynaktır. Ayrıca ormanların yeşil ve yaşam alanlar olduğu da bu gelir grubu için geçerlidir. Geliri 4.001+TL olan katılımcılarda ise ormanlar yeşil alanlar ve rekreasyon alanları olarak algılanmaktadır.

Tablo 12. Basit uyum analizi özeti.

\begin{tabular}{lllllll}
\hline Boyut & $\begin{array}{l}\text { Tekil } \\
\text { Değer }\end{array}$ & $\begin{array}{l}\text { Eylemsizlik } \\
\text { değeri }\end{array}$ & Ki-Kare & Anlamlılı & \multicolumn{2}{l}{ Eylemsizlik Oranı } \\
\cline { 5 - 6 } & & & & Hesaplanan & Kümülatif \\
\hline 1 & 0,811 & 0,658 & 309,779 & $0,000 \mathrm{a}$ & 0,847 & 0,847 \\
2 & 0,345 & 0,119 & & & 0,153 & 1,000 \\
Toplam & & 0,776 & & & 1,000 & 1,000 \\
\hline
\end{tabular}


Tablo 12 incelendiğinde eylemsizliğin 0'dan farklı olup olmadığına yönelik yapılan Ki-Kare analizi neticesinde toplam eylemsizliğin 0 'dan farklı olduğu görülmektedir $\left(\chi^{2}=30,779 ; \mathrm{p}<0,05\right)$. Buna göre satır ve sütun değişkenlerinin birbirinden bağımsız olmadığı yani aralarında bir ilişki olduğunu söylemek mümkündür. Tabloda boyutların etki derecelerinin belirlendiği eylemsizlik oranı sütununda görüleceği üzere birinci boyut toplam eylemsizliğin \%84,7’sini açıklamaktadır. Şekil 5 için açıklamalar birinci boyuta göre yapılacaktır.

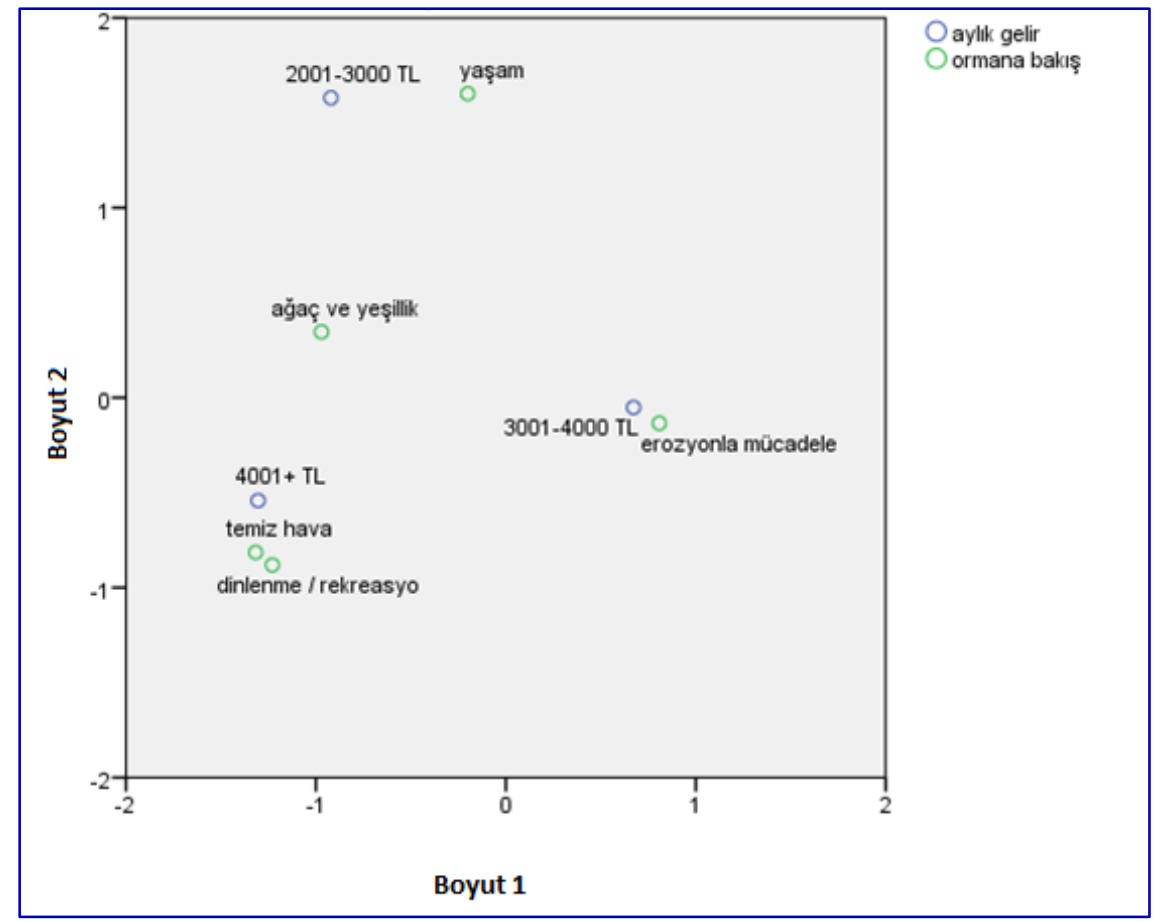

Şekil 5. Satır ve sütun noktalarının düzlemde birlikte gösterimi.

Satır ve sütun noktalarının düzlemde birlikte gösterildiği Şekil 5'de gösterildiği üzere, geliri 2.000-3.000 TL olanlar için ormanlar yaşam alanı şeklinde algılanırken, 4.001+ TL geliri olan katılımcılar için ormanlar temiz hava kaynağı ve dinlenme/rekreasyon alanı olarak algılanmaktadır. Hem 2.000-3.000 TL geliri olanlar hem 4.001+TL gelirli katılımcılar için ormanlar aynı zamanda ağaç ve yeşil alanlar olarak görülmektedir. Bunlara karşılık, 3.001-4.000TL gelirliler için ormanlar erozyonla mücadelede önemli bir unsur olarak algılanmaktadır.

Tablo 12. Ormana bakış açısına göre teşkilattan beklenti.

\begin{tabular}{llllllll}
\hline $\begin{array}{l}\text { Ormana } \\
\text { bakış }\end{array}$ & $\begin{array}{l}\text { Orm. } \\
\text { alan } \\
\text { artırımı }\end{array}$ & $\begin{array}{l}\text { Orm. } \\
\text { koruma }\end{array}$ & $\begin{array}{l}\text { Eroz. Sel } \\
\text { mücadele }\end{array}$ & $\begin{array}{l}\text { Düzenli } \\
\text { av }\end{array}$ & $\begin{array}{l}\text { Orm. } \\
\text { tanıtıcı gezi } \\
\text { vs. }\end{array}$ & Süreklilik & Toplam \\
\hline Yeşillik & 211 & 23 & 8 & 1 & 7 & 7 & 257 \\
Temiz hava & 41 & 13 & 8 & 1 & 1 & 1 & 65 \\
Yaşam & 15 & 4 & 1 & 3 & 3 & 3 & 29 \\
Rekreasyon & 7 & 5 & 1 & 1 & 3 & 1 & 18 \\
Yaban hayatı & 4 & 1 & 2 & 1 & 2 & 2 & 12 \\
Erozyonla & 3 & 2 & 1 & 1 & 1 & 2 & 10 \\
mücadele & & & & & & 1 & 8 \\
$\begin{array}{l}\text { Odun üretimi } \\
\text { Toplam }\end{array}$ & 1 & 2 & 1 & 1 & 2 & $\mathbf{1 7}$ & $\mathbf{3 9 9}$ \\
\hline
\end{tabular}

Ormana bakış açısına göre teşkilattan beklentilerin neler olduğu sorusuna verilen cevapların dağılımını gösteren Tablo 12'ye göre, ormanı yeşillik olarak ve temiz hava kaynağı olarak algılayanların teşkilattan beklentileri orman alanlarının artırılması ve korunması şeklindedir. Ormana bakış açılarını içeren diğer seçenekler ile teşkilattan beklentiler arasında dengeli bir dağılım olduğu da görülmektedir. 
Tablo 13. Basit uyum analizi özeti.

\begin{tabular}{lllllll}
\hline Boyut & $\begin{array}{l}\text { Tekil } \\
\text { Değer }\end{array}$ & $\begin{array}{l}\text { Eylemsizlik } \\
\text { değeri }\end{array}$ & Ki-Kare & Anlamlılı & \multicolumn{2}{l}{ Eylemsizlik Oranı } \\
\cline { 5 - 6 } & 0,433 & 0,188 & 100,763 & $0,000 \mathrm{a}$ & 0,744 & Kümülatif \\
\hline 1 & 0,196 & 0,38 & & 0,152 & 0,744 \\
2 & 0,126 & 0,016 & & 0,063 & 0,896 \\
3 & 0,087 & 0,008 & & 0,030 & 0,959 \\
4 & 0,052 & 0,003 & & 0,011 & 0,989 \\
5 & & 0,253 & & 1,000 & 1,000 \\
Toplam & & & & 1,000 \\
\hline
\end{tabular}

Tablo 13'teki değerler dikkate alındığında yapılan Ki-Kare analizi neticesinde toplam eylemsizliğin 0'dan farklı olduğu görülmektedir $\left(\chi^{2}=100,763 ; p<0,05\right)$. Buna göre satır ve sütun değişkenlerinin birbirinden bağımsız olmadığı yani aralarında bir ilişki olduğunu söylemek mümkündür. Tabloya göre boyutların etki derecelerinin belirlendiği eylemsizlik oranı sütununda görüleceği üzere birinci boyut toplam eylemsizliğin \%74,4’ünü açıklamaktadır. Dolayısıyla Şekil 6 için yapılacak açıklamalar birinci boyuta göre yapılacaktır.

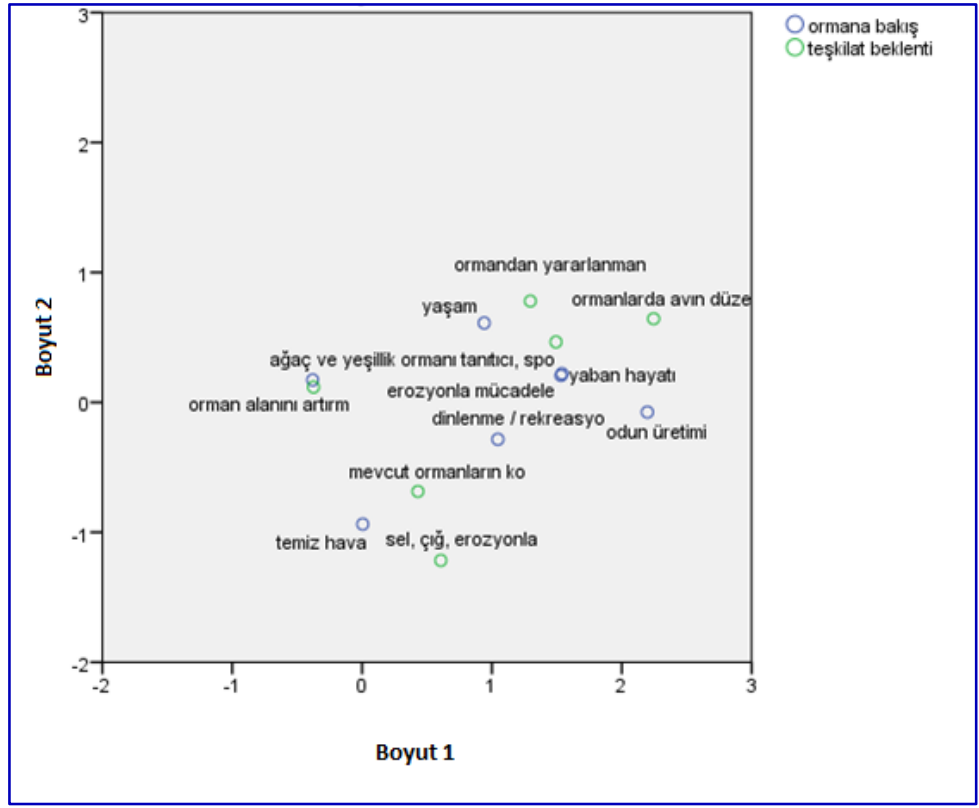

Şekil 6. Satır ve sütun noktalarının düzlemde birlikte gösterimi.

Şekil 6'ya göre, ormanları ağaç ve yeşillik alanlar olarak görenlerin teşkilattan beklentisi orman alanlarının artırılmasıdır. Buna karşılık, ormanı temiz hava ve dinlenme/rekreasyon alanı olarak görenlerde beklentiler mevcut ormanların korunması ve sel, çı̆̆ ve erozyonla mücadele edilmesi şeklindedir. Ormanları yaşam alanı ve yaban hayatı olarak algılayanların teşkilattan beklentileri ise ormandan yararlanmanın artırılması, ormanları tanıtıcı faaliyetler ve ormanlarda düzenli av yapılmasının sağlanması olduğu söylenebilir. Ormanları odun üretim alanları olarak görenlerin beklentileri için de ormanı tanıtıcı faaliyetler ve ormanlarda düzenli av yapılmasının olduğu şeklindedir.

Tablo 14. Ormana bakış durumuna göre ormandan faydalanma şekilleri.

\begin{tabular}{lllll}
\hline Ormana bakıș & Yakacak odun & Avlanma & Piknik, kamp, spor & Toplam \\
\hline Yeşillik & 6 & 24 & 65 & 95 \\
Temiz hava & 2 & 1 & 7 & 10 \\
Yaşam & 2 & 13 & 15 & 30 \\
Rekreasyon & 1 & 4 & 45 & 50 \\
Erozyonla & 1 & 2 & 211 & 214 \\
mücadele & $\mathbf{1 2}$ & $\mathbf{4 4}$ & $\mathbf{3 4 3}$ & $\mathbf{3 9 9}$ \\
Toplam & & & & \\
\hline
\end{tabular}


Tablo 14'e göre ormanı yeşil alanlar, yaşam alanı, rekreasyon alanı olarak algılayanların ormanlardan faydalanma şekilleri ağırlıklı olarak piknik ve avlanma şeklindedir. Ormanları temiz hava kaynağı ve erozyonla mücadelede etkin bir faktör olarak görenlerde ağırlıklı faydalanma şekli piknik, kamp, spor vb. şeklindedir.

Tablo 15. Basit uyum analizi özeti.

\begin{tabular}{lllllll}
\hline Boyut & $\begin{array}{l}\text { Tekil } \\
\text { Değer }\end{array}$ & $\begin{array}{l}\text { Eylemsizlik } \\
\text { değeri }\end{array}$ & Ki-Kare & Anlamlılık & Eylemsizlik Oranı & \\
\cline { 5 - 6 } & & & & Hesaplanan & Kümülatif \\
\hline 1 & 0,470 & 0,221 & 97,477 & $0,000 \mathrm{a}$ & 0,903 & 0,903 \\
2 & 0,154 & 0,024 & & & 0,097 & 1,000 \\
Toplam & & 0,244 & & & 1,000 & 1,000 \\
\hline
\end{tabular}

Tablo 15 incelendiğinde eylemsizliğin 0'dan farklı olup olmadığına yönelik yapılan Ki-Kare analizi neticesinde toplam eylemsizliğin 0'dan farklı olduğu görülmektedir $\left(\chi^{2}=97,477 ; \mathrm{p}<0,05\right)$. Buna göre satır ve sütun değişkenlerinin birbirinden bağımsız olmadığı yani aralarında bir ilişki olduğunu söylemek mümkündür. Tabloda boyutların etki derecelerinin belirlendiği eylemsizlik oranı sütununda görüleceği üzere birinci boyut toplam eylemsizliğin \%90,3’ünü açıklamaktadır. Bu durumda, Şekil 7 için açıklamalar birinci boyuta göre yapılacaktır.

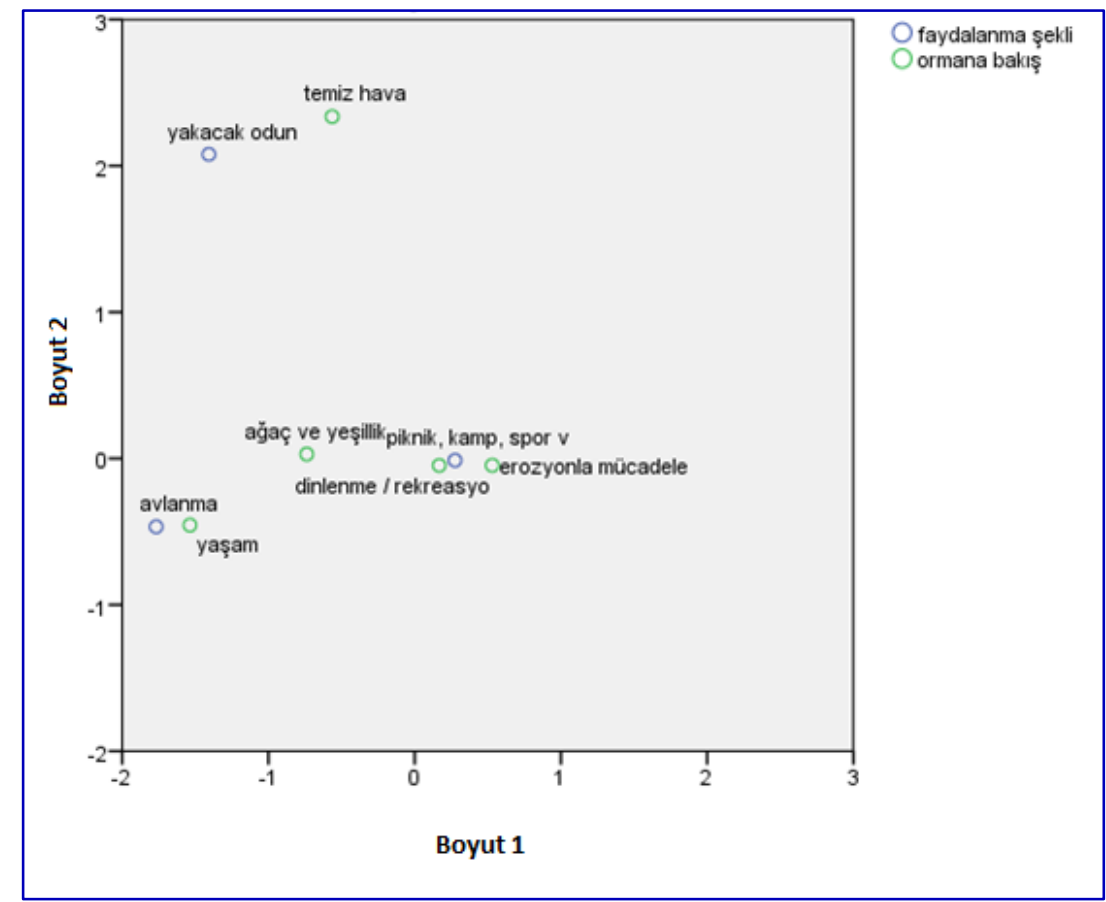

Şekil 7. Satır ve sütun noktalarının düzlemde birlikte gösterimi.

Satır ve sütun noktalarının düzlemde birlikte gösterildiği Şekil 7'de gösterildiği üzere, ormanı temiz hava ortamı olarak algılayanların faydalanma şekli yakacak odundur. Ormanı yaşam alanı olarak görenlerin ise başlıca faydalanma şeklinin avlanma olduğu görülmekteyken ormanı ağaç ve yeşillik alan olarak görenlerin de faydalanma şeklinin avlanma olduğu söylenebilir. Bunlara karşılık, ormanları bir dinlenme/rekreasyon alanı ve erozyonla mücadele unsuru olarak görenlerin faydalanma şeklinin piknik, kamp, spor vb. olduğu görülmektedir. Ormanları temiz hava kaynağı olarak algılayanların ormanlardan birbirine yakın düzeylerde avlanma ve piknik, kamp, spor vs. şeklinde faydalandıkları da söylenebilir.

\section{Sonuç ve Öneriler}

Çevresel tehditlerin aşırı nüfus yı̆̆ılmaları ve yapı stokları nedeniyle ağırlıklı olarak kentlerde görüldüğü söylenebilir. Kentleşme söylemine; sürdürülebilir kent, eko-kent, yeşil-şehircilik, organik şehircilik, biyofilik 
kent gibi kimi yeni kavramlar ve anlayışlar eklenmiştir (Kale, 2019). Toplumların uygarlık düzeyine koşut bir gelişme gösteren yeşil alan ve nitelikleri günümüzde bir yandan planl gelişen kentlerin vazgeçilmez öğeleri olurken diğer yandan çağdaş kent kavramında sosyokültürel yaşam niteliğinin birer göstergesi durumuna gelmiş̧tir (Demirel vd., 2005). Kentlerin yeşil alan yoksunluğu, kent toplumunun yeşil alanlara olan ihtiyacını ve talebini daha da arttırmıştır (Kurdoğlu ve Düzgüneş, 2011). Günümüzde kentlerin daha sağlıklı yaşam yerleri olması ve ekolojik, sosyal ve ekonomik katkılarının sağlanması yönünde yoğun çalışmalar yapılmaktadır (Kurdoğlu vd., 2011). Açık-yeşil alanlar, insan ile doğa arasındaki bozulan ilişkiyi dengelemede ve kentsel yaşam koşullarının iyileştirilmesinde önemli bir konuma sahiptir (Yılmaz vd. 2006). Kentlerde yaşayanların hareketli yaşam şekilleri nedeniyle aralarındaki bağlar göreli olarak zayıftır. Bunun da etkisiyle, modern dünyanın karmaşıklığına bir tepki olarak kırsal alanlar ve mekânlar yeni bir sosyalleşme imkânı sunmaktadır (Giddens, 2000; Bessiere, 1998). Atmiş (1999)'a göre de köylerden kentlere doğru yaşanan göç olgusu kentli nüfusta bir yoğunlaşmaya yol açmıştır. Bu durum ise, çeşitli çevre sorunlarının ortaya çıkmasıyla sonuçlanmış ve toplumun ormana bakış açısının değişmesine neden olmuştur. Ankara ili merkezinde 399 katılımcı ile yapılan bu çalışma ile toplumun ormana yaklaşımı, ormandan beklentileri ve orman konusundaki farkındalıklarının tespit edilmesi hedeflenmiştir. Daha önce farklı alanlarda yapılmış çalışmaların sonuçları göz önüne alındığında toplum genelinde ormanların ağırlıklı olarak ağaçlık, yeşil alanlar olduğu, ormanlardan çoğunlukla piknik yapma amaçlı faydalanıldığı, ormanların geniş seçenekli işlevlerinin toplumda kısıtlı olarak bilindiği, ormancılık teşkilatı ve çalışmaları konusunda ise toplumda yeterince bilgi sahibi olunmadığı görülmektedir. Ormancıllk faaliyetlerinin gerçekleştirilmesi sürecinde orman köylülerinin bilgilendirilmesi yanı sıra kentlerde yaşayan insanların orman algılarını geliştirmek, daha etkili ve yeterli bir bilgi akışını sağlamak adına teşkilatın kitle iletişim araçlarını kullanılması büyük önem arz etmektedir. Orman kaynaklarının birçok işlevine yönelik bilinç düzeyinin geliştirilmesi hem günümüz ihtiyaçları ve hem de gelecek kuşaklar için sürdürülebilir kaynak yönetimi açısından vazgeçilmezdir.

Araştırma neticesinde orman kaynaklarının işlevleri ve toplumsal bilinç konusunda kesin bir yargıya varmanın zor olduğu görülmektedir. Elde edilen neticeler de göstermiş̧ir ki katılımcıların orman işlevlerinden bir kısmı ile ilgili yeterli farkındalığa sahip değildir. Bunlardan bazıları ormanların biyolojik çeşitliliğin korunmasına etkisi, ormanların iklim üzerine etkisi, ormanların toplum sağlı̆̆ına etkisi, kültürel ve ormanların yöresel değerlerin korunmasına etkisi, ormanların odun dışı orman ürünü sağlaması, rekreasyon imkânı sunması şeklindedir. Buna karşılık, orman kaynaklarının temiz ve kaliteli su üretimi, erozyonla toprak taşınmasının engellenmesi, doğal besin sağlama, hava temizliği, kırsalda iş imkânı sağlama gibi işlevleri konusunda ise yüksek bir farkındalığa sahip olduğu görülmektedir. Bu sonuçlara bakılarak, insanların ormanların işlevleri konusunda kısıtlı bilgi sahibi olduğu söylenebilir. Bu durumun oluşmasında özellikle şehirlerde yaşayan insanların birçoğunun ormandan uzak olması yanında teşkilat olarak gerekli tanıtımların ve bilgilendirmelerin yetersiz yapılmasının etkili bir unsur olduğu söylenebilir. Bu çalışmaya benzer bir çalışmada, Yurdakul Erol ve Yıldırım (2017) sosyoekonomik değişkenlerin orman fonksiyonlarına göre ormanların alansal dağılımı etkilediğini tespit etmişlerdir. Pak ve Berber (2011)'in sonuçlarına göre, katılımcıların \%70,4'ünün orman kaynaklarının işlevleriyle ilgili olarak yüksek düzeyde bilinç sahibidir. Yine benzer bir çalışmada Atmış (1999) toplumun büyük bir kesiminde orman hizmetleri konusunda bilgi sahibi olduğunu dile getirmiştir. Bu sonuçların çalışma sonuçlarıyla kısmen benzerlik gösterdiğini söylemek mümkündür.

Orman kaynaklarına yönelik farkındalıkta cinsiyet, yaş, eğitim durumu, meslek, gelir düzeyi ve kaynaktan faydalanmaya göre ortaya çıkan farklı sonuçlar araştırma açısından önem arz etmektedir. Çalışmada da bu değiş̧kenler açısından analizlere ve değerlendirmelere yer verilmiştir. Tablo 5'de bu değişkenlerden cinsiyet, yaş, eğitim ve ormandan faydalanma şekilleri ile aralarında anlamlı ilişkilerin bulunduğu değişkenlerin özeti sunulmuştur. Buna göre, cinsiyet bakımından orman kaynakların işlevlerinin farkındalığı farklılık göstermektedir. Bu sonuç, Pak ve Berber (2011)'in çalışma sonucuyla benzerlik göstermektedir. Erkeklerin ormanların işlevleri konusunda kadınlara göre daha bilinçli ya da daha fazla bilgi sahibi olduğu görülmektedir. Orman kaynaklarının, biyoçeşitliliğin korunmasına etkisi, iklim üzerinde etkisi, besin kaynağı olması, havayı temizlemesi, kent yaşamını desteklemesi, rekreasyon imkânı sağlaması, toplum sağlığına etkisi, küresel ısınmaya etkisi, kültürel ve yöresel değerleri koruma ve odun dışı orman ürünü sağlama işlevleri konusunda erkeklerin bilinç düzeyi kadınlara göre çok daha fazladır. Kadınların erkeklere göre daha bilinçli olduğu işlevler ise; temiz ve kaliteli su sağlama, erozyonla toprak taşınmaya engel olması, kırsalda iş imkânı sağlaması şeklindedir. Bilinçlenmenin büyük oranda eğitimle kazanıldığı düşünüldüğünde, ülkemizde kadınların eğitim seviyesinin daha düşük olduğu şeklinde de yorumlanabilir.

Yaş ile orman kaynaklarının işlevlerinin bilinç düzeyi ve ormandan faydalanma şekilleri konusunda da farklılıklar olduğu söylenebilir. Buna göre; 16-25 ve 41-60 yaş grubu katılımcıların başlıca faydalanma şekli avlanma iken 26-40 yaş grubu için piknik, kamp, spor vb., avlanma, yakacak odun ve istihdam şeklinde çeşitlenmiştir. Orman işlevleriyle ilgili olarak yaş gruplarının durumuna bakıldığında ise, işlevlere göre yaş gruplarının farkındalıklarının 
da değişiklik gösterdiği görülmektedir. Biyolojik çeşitliliğin korunması, iklime etki, toplum sağlığına etki, kültürel ve yöresel değerlerin korunmasına etki konusunda $16-25$ ve 26-40 yaş gruplarının daha bilinçli olduğu söylenebilir. Buna karşılık, küresel ısınmaya etki, temiz ve kaliteli su sağlama, erozyonla toprak taşınmasının engellenmesi, doğal besin sağlaması, hava temizliği, kent yaşamını destekleme ve kırsalda iş imkânı sağlaması gibi işlevler açısından 41-60 yaş grubunun daha bilinçli olduğu sonucu ortaya çıkmıştır. Bu sonuçlar Atmış (1999); Kurdoğlu ve Düzgüneş (2011); İnanç (2019); Pak ve Berber (2011)'in çalışmasında ortaya koymuş olduğu genç yaş grubunun orman hizmetlerine daha ilgili sonucuyla çelişkili görünmektedir.

Eğitim düzeyi ile hem ormandan faydalanma şekli hem orman kaynaklarının işlevlerine bakış açısı arasında da farklılıklar olduğu çalışma neticesinde ortaya çıkan sonuçlardan biridir. Buna göre; ilkokul, önlisans/lisans, yüksek lisans ve doktora eğitimine sahip olanların ormandan faydalanmada ağırlıklı olarak tercihi piknik, kamp, spor seçeneğidir. Lise eğitimliler için de bu seçenek yakın olmakla birlikte diğer seçeneği biraz daha fazladır. Orman kaynaklarının işlevleri konusunda bilinç düzeyi açısından bakılacak olursa; hemen her işlev için eğitim düzeyinin farkındalığa etkisi farklılık göstermektedir. Şöyle ki, biyolojik çeşitliliğin korunmasına etki, iklime etkisiyle ilgili bilinç düzeyinin lise ve yüksek lisans/doktora eğitimlilerde daha fazla olduğu; küresel ısınmanın azaltılması, temiz ve kaliteli su sağlanması, doğal besin sağlanması, kent yaşamının desteklenmesi işlevleri bakımından lise, önlisan/lisans, yüksek lisans ve doktora eğitimi olanların daha bilinçli oldukları; erozyonla toprak taşınmasının engellenmesinde lisans ve doktora eğitimi olanların daha fazla farkındalık sahibi olduğu; kırsalda iş imkanı konusunda ise lise, önlisans/lisans ve yüksek lisans eğitimine sahip katılımcıların bilinç düzeylerinin daha fazla olduğu sonucuna ulaşılmıştır. Çalışmada elde edilen sonuçlar açısından Pak ve Berber (2011)'de elde etmiş olduğu eğitim düzeyinin artmasıyla çevre bilincinin de artması sonucuna, Vaizoğlu vd. (2005), Erol ve Gezer (2006) ve Atmiş (1999)'in çalışmasında eğitimle bilinç düzeyi arasındaki sonuçlar ile örtüşmemektedir.

Yurdakul Erol (2012b)'nin de ifade ettiği gibi toplumun desteği olmadan doğal kaynakları korumak mümkün değildir. Toplum ancak bildiği, anladığı ve kabul ettiği takdirde koruma süreçlerine destek verecektir. Toplumun çevre ve doğal kaynaklar ile ilgili eğitim düzeyinin geliştirilmesi ile çevrenin ve doğal kaynakların sürdürülebilir yönetimi sağlanabilecek ve olumsuz insan etkisi en alt seviyeye indirilecektir.

\section{Teşekkür}

Yazarlar anonim hakemlere ve anket çalışmalarındaki katkılarından dolayı İbrahim Öztürk’e teşekkürü bir borç bilirler.

\section{Kaynaklar}

1. Akalp, T (2016). İstatistik Yöntemler. İstanbul Üniversitesi, Orman Fakültesi Yayınları, İstanbul.

2. Akın, G (2006). Geçmişten Günümüze Anadolu Ormanları ve İnsan. Kırsal Çevre Yillı̆̆ı, s:19-31, Ankara.

3. Atmış, E (1999). Orman Toplum İlişkilerine Farklı Bir Bakış: Kentlinin Ormana Yaklaşımı (Bartın Örneği), Bartın Orman Fakültesi Dergisi, 1(2), 56-68.

4. Atmış, E (2001). Sürdürülebilir ormanc1lıkta halk katılımının ilk aşaması: Toplumun beklentilerinin tespiti. I. Birinci Ulusal Ormancillk Kongresi, Türkiye Ormanc1lar Derneği, Ankara, s:218-233.

5. Atmış, E (2003). Dünyada ve Türkiye'de ormancılıkta katılım. II. Ulusal Ormancılık Kongresi (19-20 Mart 2003) Kitabı. Türkiye Ormancılar Derneği Yayını, Ankara, s:81-101.

6. Atmiş, E (2004). Ormanlar Üzerindeki Kent Kökenli Baskılar ve Kentli Duyarlıllğı (Urban based pressures on forests and urban sensitivity). I. National Urban Forestry Congress Proceedings, 9-11 April. Society of Turkish Foresters, Ankara, s:401-413.

7. Atmış, E., Günşen, H.B (2016). Kentleşmenin Türkiye ormancılığının dönüşümüne etkisi (1990-2010 Dönemi). Journal of the Faculty of Forestry Istanbul University, 66(1), 16-29.

8. Bessiere, J (1998). Local Development and Heritage: Traditional Food and Cuisine as Tourist Attractions in Rural Areas. Sociologia Ruralis, 38/1, 21-34.

9. Birben, Ü., Ünal, H.E., Karaca, A (2018). Orman kaynaklarına ilişkin toplumsal algının incelenmesi (Çankırı kent merkezi örneği). Turkish Journal of Forestry, 19(1): 76- 82. DOI: 10.18182/tjf.394139.,

10. Daşdemir, İ (2016). Bilimsel Araştırma Yöntemleri. Nobel Akademik Yayıncılık ve Danışmanlık Tic. Ltd. Şti., Yayın No: 1536, ISBN 978-605-320-442-8, 210 s., Ankara.

11. Demirel, Ö., Pirselimoğlu, Z., Sarıkoç, E., Özdemir, B (2005). Kent Ormanlarının Sosyal ve Çevresel İşlevlerinin Kullanıma Dayalı Bozulma Süreci, Atatürk Üniversitesi, Ziraat Fakültesi Dergisi, 36 (2), 201208.

12. Erol, G.H., Gezer, K (2006). Prospective of elementary school teachers' attitudes toward environment and environmental problems. International Journal of Environmental and Science Education, 1 (1), 65-77. 
13. Ertuğrul, M (2010). Orman Yangınlarının Yerleşim Alanlarına Etkisi ve Koruma Yöntemleri, Bartın Orman Fakültesi Dergisi 12(17): 101-109.

14. Giddens, A (2000). Sosyoloji. Ankara: Ayraç Yayınevi.

15. Kale, B (2019). Kent Ormanlarının Sunduğu Ekolojik Hizmetler, Kent Akademisi, Volume, 12(39), 3, 420440.

16. Kılı̧, A.F (2016). Uyum Analizi, YBS Ansiklopedisi, Cilt:3, Say:1, s.1-20.

17. Kurdoğlu, O., Düzgüneş, E. (2011). Artvin kent ormanının rekreasyon olanakları ve kullanıcı tercihlerinin irdelenmesi, Artvin Çoruh Üniversitesi Orman Fakültesi Dergisi 12 (2), 199-210.

18. Kurdoğlu, O., Düzgüneş, E. Kurdoğlu, B., Ç (2011). Kent Ormanlarının Kavramsal Hukuksal ve Çevresel Boyutuyla Değerlendirilmesi, Artvin Çoruh Üniversitesi Orman Fakültesi Dergisi, 12 (1):72-85.

19. Mutlu B. E., Cengiz, B (2017). Uzman Perspektifinden Bolu Kent Ormanı’nın Çok Fonksiyonlu Kullanım Özelliklerinin Değerlendirilmesi Üzerine Bir Araştırma, Iğdır Üniversitesi Fen Bilimleri Enstitüsü Dergisi, 7(4): 213-222.

20. Orhunbilge, A. N (2000). Örnekleme Yöntemleri ve Hipotez Testleri (Gözden Geçirilmiş ve Genişletilmiş İkinci Bask1). ISBN 9789758345045, Avcıl Basım ve Yayın, 420 s, İstanbul.

21. Özarslan, M (2003). Türk Kültüründe Ağaç ve Orman Kültü, Türkbilig, 5, 94-102.

22. Özdamar, K (2002). Paket Programlarla İstatistiksel Veri Analizi-1, Kaan Kitabevi, 681 s.,Eskişehir.

23. Özdamar, K (2010). Paket Programlarla İstatistiksel Veri Analizi-2, Kaan Kitabevi, 681s.,Eskişehir

24. Pak, M. ve Berber, H (2011). Orman kaynaklarının işlevlerine ilişkin toplumsal bilinç düzeyinin incelenmesi: Eskişehir ili örneği, Artvin Çoruh Üniversitesi Orman Fakültesi Dergisi, 12(2): 161-171.

25. Sağlam, B., Öztürk, A (2008). Orman Koruma Faaliyetlerinde Etkinliğin Artırılmasında Orman KöylüsüOrmancılık Teşkilatı İlişkileri: Artvin Orman Bölge Müdürlüğü Örneği, Kastamonu Üniversitesi, Orman Fakültesi Dergisi, 8(2), 131-143.

26. Sevgi, O (2013). Orman(-Lar), Ormanlık Alan ve Orman Alanı Terimleri: Kullanım Sorunları ve Öneriler, Avrasya Terim Dergisi, 1 (1): 59 - 73

27.Şen, G., Toksoy, D (2006). Türkiye'de nüfus orman ilişkisi. Ormancılıkta Sosyo-Ekonomik Sorunlar Kongresi Bildiriler Kitabı, 26-28 Mayıs 2006. Ilgaz-Çankırı, s:108-117.

28. Vaizoğlu, S., Altıntaş, H., Temel, F., Ahrabi, F.A., Aydoğan, D., Bostancı, S., Duran, A., Koçkesen, D., Turan, N., Güler, Ç (2005). Bir tıp fakültesi son sınıf öğrencilerinin çevre bilincinin değerlendirilmesi. TSK Koruyucu Hekimlik Bülteni, 4 (4), 151-171.

29. Yavuz, H. (2000). Parametrik Olmayan İstatistiksel Yöntemler, 464s, Trabzon.

30. Yılmaz, S., Bulut, Z., Yeşil, P (2006). Kent Ormanlarının Kentsel Mekâna Sağladığı Faydaları, Atatürk Üniversitesi Ziraat Fakültesi Dergisi, 37 (1), 131-136.

31. Yurdakul Erol, S (2011). Edremit Yöresinde Orman Kaynakları Yönetim Stratejileri, International Symposium on Kazdağları (Mount Ida) and Edremit: Global Change in the Mediterranean Region Turkey, s:567-576.

32. Yurdakul Erol, S (2012a). Differences between urban and rural population with respect to demand on forestry aspects, in a case study of the Turkish province of Balıkesir. Ciência Rural, 42(3), 436-443.

33. Yurdakul Erol, S (2012b). Çevre politikası aracı olarak eğitim ve bilinçlendirme çalışmaları ve Akdeniz bölgesi için işlevsel önemi. KSÜ Doğa Bilimleri Dergisi, Özel Sayı, 185-192.

34. Yurdakul Erol, S., Yıldırım, H.T (2017). Investigation of relations between forest functions and some socioeconomic variables: The case of Turkey. Journal of the Faculty of Forestry Istanbul University 67(2): 123-135. DOI: 10.17099/jffiu.298588.

35. Yurdakul Erol, S., Şahin, G (2017). Kent Konseyi Kararlarının Kentlerdeki Orman Alanlarının Katılımcı Yönetimi Açısından İrdelenmesi: İstanbul Örneği. Kastamonu University Journal of Economics \& Administrative Sciences Faculty, 18(1), 214-225. 